\title{
Negotiating Love and Faith: Interfaith Marriage in Manado, Indonesia
}

\author{
Rosdalina Bukido ${ }^{*}$, Edi Gunawan², Djamila Usup ${ }^{3}$, Hayat ${ }^{4}$ \\ 1 Institut Agama Islam Negeri Manado, Indonesia; e-mail: rosdalina.bukido@iain-manado.ac.id \\ 2 Institut Agama Islam Negeri Manado, Indonesia; e-mail: edigunawan@iain-manado.ac.id \\ 3 Institut Agama Islam Negeri Manado, Indonesia; e-mail: djamila.usup@iain-manado.ac.id \\ 4 Universitas Islam Malang, Indonesia; e-mail: hayat@unisma.ac.id \\ * Correspondence
}

Received: 2021-02-01; Accepted: 2021-07-31; Published: 2021-08-20

\begin{abstract}
Interfaith marriages in people's lives have been practised in many areas in Indonesia, even if it's not legally registered. The rule of law in Indonesia does not accommodate interfaith marriages. When interfaith marriage happens, the registration system should follow marriage registration either at the KUA (office of religious affairs) for Muslims or in the Civil Registry office for other religions. This study aims to analyse the practice of interreligious marriage in Manado and how they maintain a good marital relationship between the spouse of different religions. This research employs a qualitative approach by collecting data through interviews with 30 informants who practice interfaith marriages in Manado. The results of this research found that many people in Manado consider interfaith marriage as permissible. They argue that religion is a relationship between humans and God, while marriage is related to human beings. The family of different religions based their relationship on the principle of "Torang Samua Basudara" (we are bound through kinship). Based on this principle, the family avoids using religious symbols in their communication that can cause tension and disrupt harmony among family members. The principle of torang samua basudara is the basis for establishing good communication in the family.
\end{abstract}

Keywords: Different religion; family; marriage; motive; religious symbol.

Abstrak: Pernikahan beda agama dalam kehidupan masyarakat sudah banyak ditemukan di Indonesia sekalipun tidak tercatat secara sah. Aturan hukum di Indonesia tidak menganut perkawinan beda agama. Sistem tersebut terintegrasi dengan pencatatan perkawinan baik di KUA ataupun di Catatan Sipil, langkah ini dilakukan karena pernikahan beda agama memberikan sebagian besar dampak yang tidak baik bagi masyarakat. Penelitian ini bertujuan untuk menganalisis alasan masyarakat Kota Manado menikah dengan pasangan yang memiliki agama yang berbeda dan masih bisa hidup dengan baik dan dapat membina keluarga yang harmonis. Metode dalam penelitian ini adalah menggunakan pendekatan kualitatif dengan pengambilan data melalui wawancara kepada 30 informasi untuk dijadikan sumber analisis pernikahan beda agama di Kota Manado. Hasil yang ditemukan bahwa penyebab yang membentuk keluarga beda agama karena adanya persepsi bahwa di masyarakat Manado tidak melarang membangun keluarga beda agama. Agama merupakan urusan antara hamba dan Tuhannya sedangkan perkawinan urusan antara sesama manusia. Dalam membentuk keluarga beda agama, di Manado menerapkan pola komunikasi "Torang Samua Basudara" (Kita semua bersaudara), sehingga dalam berkomunikasi tidak membawa simbol-simbol keagamaan yang dapat mengganggu keharmonisan di antara para anggota keluarga. Prinsip torang semua basudara inilah yang menjadi landasan dalam menjalin komunikasi dalam keluarga.

Kata Kunci: Beda agama; keluarga; motif; pernikahan; simbol keagamaan. 


\section{Introduction}

Interfaith marriages refer to marriages between spouses who adhere to different religions (Çiğdem, 2015). Interfaith marriages (families of different religions) are increasingly being discussed and are gaining momentum and relevance in society. The problem of interfaith marriages in people's lives has been discussed in academic seminars and in public discussions due to the increase of its practice in many regions in Indonesia, especially areas where society is very diverse. This practice becomes a hot topic debated especially related to the prohibition by certain authorities, such as the Indonesian Ulema Council (MUI), which forbids interfaith marriages (Jauhari \& Ghoni, 2020; Yusuf, 2013). The debate is also become controversial due to the rise of religious conservatism in Indonesia in recent years, leading its adherents to be more conservative and intolerant to other religions.

Interfaith marriage in this article refers to a marriage carried out by a prospective husband and wife that belong to a different religion. Before the marriage took place, there was an agreement between the parties not to problematise their religious affiliation. This article uses the term interfaith family to imply a legal marriage according to law and religion.

North Sulawesi is the land of waving palm trees, symbolising the diversity of cultures, ethnicities, and religions famous for its motto 'Torang Samua Basudara,' which means 'We are all brothers/sisters.' It refers that the community bond is through the kinship system. Manado is the capital city of North Sulawesi Province and has 427,906 people (2017). Manado society consists of various tribes, namely Minahasa, Bolaang Mongondow, Gorontalo, Sanger, Makassar and Bugis. Manado residents are mostly migrants from different areas of Sulawesi, thus there is no particular indigenous tribe live in Manado. Manado is known as the city of a thousand churches, which indicates that most of the population is Christian. There are several Catholic, Protestant, Islam, Hinduism, Buddhism, and Confucianism in this city. Manado is also known to be harmonious in inter-religious relations. One of them is the interaction in the marital relationship where family members belong to different religions. The pattern of marital relations in Manado varies.

Marriage institutions in Indonesia are established in Marriage Law no. 1 of 1974 concerning marriage. Article 1 states that marriage is based on the people's belief in One God, which means any religious marriage is based on divinity. Further, article 2 explains that marriage is legal if it is carried out according to the laws of each religion and belief, and the marriage must be recorded according to the applicable laws and regulations. It can be interpreted that interreligious marriage should not be accommodated. It is assumed that interreligious marriage can cause uncertainty in the religious belief of the children.

For the couple whose spouses are Muslim, the marriage should be registered in the office of Religious Affairs (KUA - Kantor Urusan Agama). Meanwhile, the registration should be lodged to the Civil Registry Service Office for the couple other than Muslims.

Marriage patterns of different religions are varied. Some of the marriages have a pre-marital agreement that each couple would stay in their own religion; or the couple agreed that one of them would follow their partner's religion either the groom follow the bride or otherwise (Hutapea, 2011). Several cases also show that one of the partners would return to the couple's original religion after marriage. Harmonious marriage can be maintained through the commitment of both spouses. Some factors can influence the success or the failure of a marriage. Several of them is the relationship with the extended family, who interfere with the household affairs in many cases. Managing the marriage to be a success is based on the commitment of both parties (Hutapea, 2011).

The concept of an interfaith family that decides to separate in the affairs between love and belief becomes a solid foundation and commitment that is respected in building the family (Muhammad, 2020; Syatriadin, 2019). Humans as social beings do not limit their interaction with the person who comes from one religion, but in fact, with various backgrounds (Ruandini, 2011). When it comes to the relationship that leads to marriage, the community should respect the couples' decision to either stay in each other religion or one of them convert to one party's religion. In this case, people should maintain both the love and the belief of the couples. 
In North Sulawesi, the phenomena of families of different religions are common. North Sulawesi contains a culture open to many religions, especially in Manado, the city of heterogeny based on religion and ethnic origin. The slogan of Torang Samua Basudara is a symbol of brotherhood for fellow believers and a symbol that practice in marriage life (Mantu, 2018). This paper explores the negotiations between love and faith in interreligious marriages. Love is an early relationship that has been framed with full responsibility. At the same time, belief is a guide to life where it is something that religious adherents must account for to their God.

This article is qualitative research attempting to describe, analyse, and interpret the data collected in the research process. This article is exploratory with a descriptive-analytical method prioritising families of different religions in the people of Manado. This study aims to understand how the people of Manado can maintain their families despite different religions and how the domestic life of interfaith marriages is. Interviews were conducted with 30 informants, including community leaders, religious leaders, KUA officers, Civil Registry officers in Manado City, and the main respondents who practice interfaith marriages. In addition to interviews with all informants, the authors also conducted observations, documentation studies, and literature studies that are then analysed interactively and continuously in the field, consisting of three activities: data reduction, data display, and conclusion drawing/verification.

\section{The Regulation of Interfaith Marriage in Indonesia}

Muslim jurists, except for a few 20th-century scholars, unanimously hold that Muslim women may not marry non-Muslim men. However, Muslim men may marry non-Muslim women of ahl al-kitāb, that is Christians or Jews (Çiğdem, 2015). It is said that 'Marriage should be contracted between the people who share the same religion.' This statement is a misleading analogy because, for Cigdem, a marriage is based on love, mutual respect, and understanding and cannot be compared to any other things like politics or economic that do not involve love in its decision.

Every marriage will have its ups and downs relationships, but interfaith marriages have some extra challenges. For example, in Malaysia, research by Sintang et al. mentioned that there is a clear division of jurisdiction in family law between civil and sharia courts; non-muslims can only marry Muslims after converting to Islam (Sintang, Khambali, Baharuddin, \& Ahmad, 2014). According to this research, interfaith marriage can have a double-edged sword effect. It has several benefits and, at the same time, can cause harm. Many believed that the harmful effect (mafsadah) is greater than its benefit (maslahah), thus, Islam suggests not to practice this interreligious marriage (Islam, 2014). Besides, it is assumed that interreligious marriage will cause many problems and impossible to create a sakinah (harmonious) family (Jalil, 2018). In Nigeria, interfaith marriages are only permitted for Muslim men and non-Muslim women (Imam, 2016). In the Mediterranean, individuals and groups adjust to a new and changing political and religious context as interreligious marriages occur parallelly, intertwining with religious conversions in complex ways (Sant-Cassia, 2018).

Different interpretations of Sharia Law (Islamic Law) exist in several countries concerning the possibility of accepting this practice experienced in each country. In turn, these experiences can affect Muslims' attitudes regarding interfaith marriages (Van Niekerk \& Verkuyten, 2018). And this research by van Niekerk and Verkuyten (2018), conducted in 22 countries, reported that perceived religious similarity was associated with more positive attitudes.

However, the experience is quite different in Indonesia since it is implied in the regulations of marriage that do not allow interreligious marriage. It is stated in the Marriage Law Number 1 of 1974 article 2 paragraph (1) states: 'marriage is valid if it is carried out by the religious law and beliefs of each party. Islam is the majority religion in most parts of Indonesia. Several regions, however, have its majority of other religions like the Hindu majority in Bali province, the Catholic majority in East Nusa Tenggara province, the Christian majority in North Sulawesi, West Papua and Papua Provinces, and other areas with equal proportions of Islam and Catholicism (Aini, Utomo, \& McDonald, 2019).

Some Indonesian people who intend to practice interfaith marriages choose to conduct it in another country. It is because the regulations regarding interfaith marriage in Indonesia are unclear. In 
addition, most people who wish to have interfaith marriages find it difficult to register their marriage to the Civil Registry Service Office. The office cannot register interfaith marriages because there are no religions and practices that allow such marriages.

Indonesia has regulations that regulate human rights, namely the rights inherent in human beings by nature, universal and eternal. The regulations include the right to life and have a family, the right to develop oneself, the right to communicate, justice, independence, and security and welfare rights (Baso \& Nurcholis, 2010). Human Rights, Marriage comes from the agreement of two parties. Interfaith marriages of the United Nations Convention on Civil Rights Decisions state that there is no intervention on people and their families to choose their life partner.

Marriage Law Number 1 of 1974 does not recognise interfaith marriages. The law only considers marriages to be valid based on the laws of the respective religions. In the teachings of Islam, the exegetes (mufassir) agree that marriage to non-Muslim women is allowed as long as the woman still adheres to the teachings of ahl al-Kitab, as stated in the Qur'an. However, when her belief deviated from it, it is forbidden to marry.

The prohibition of interfaith marriages has existed before Indonesia's independence. At that time, several regions in Indonesia adhered to indigenous religions and then followed by the influence of Hinduism and Buddhism. The practice of marriages is carried out according to religious teachings with local customary rules. There is a tendency to prohibit or discourage marriage between parties of different religions or other groups (Abubakar, 2008).

Regarding interfaith marriages that occur in Indonesia, different opinions emerged between Muslims and Christians. The Islamic religious elites argue to obey the existing laws in Indonesia and that person should deepen religious understanding to avoid interfaith marriages. In contrast, the Christian religious elite responding to religious conversions caused by marriage is more open as it falls within the individual free choice regarding one's faith. When the marriage involved religious conversion, the couples should maintain the harmony of the marriage and the commitment to make it work (Jihaduddin, 2015).

Several religious groups impose restrictions on their members not to marry someone outside their religion (Kurttekin, 2020). In Indonesia, interfaith marriages are not supported by many regulations such as the Marriage Law Number 1 of 1974 concerning Marriage Chapter 1 Article 2 paragraph (1), the Compilation of Islamic Law Article 40 paragraph (c) and Article 44, the MUI Fatwa, and the Constitutional Court decision Number: 68/PUU-XII/2014, all of which banned interfaith marriages. Therefore, the Office of Religious Affairs (KUA) and the Civil Registry office will not carry out administrative records of interfaith marriages. Practising interfaith marriage is considered ignorant to these laws and regulations of the country.

The consequences of the prohibition of interfaith marriages and difficulty in registration of the marriage caused several fundamental problems regarding the rights of the citizens. They are, for example, have no marriage certificate informing that they are a married couple. When the children born from this marriage could not get a birth certificate while this certificate is usually a requirement to apply for school. In June 2015, Indonesia's Constitutional Court rejected a petition for judicial review of the 1974 Marriage Law. The plaintiffs argued that the current interpretation of the law violated the right of interfaith couples to marry (Aini et al., 2019).

The laws in Indonesia regarding marriage show that it is difficult to have interfaith marriage to be recorded officially. Following the fatwa of the Ulama Indonesian Council that banned interreligious marriage, the marriage registrars in each district are prohibited from recording the marriage involving non-Muslims (Patricktts, 2010).

The legal consequences of unregistered interfaith marriages will impact marital status, the status and position of children, and inheritance relationships (Zuriyati, Yaswirman, \& Yasniwati, 2019). Since the validity of the marriage is the main requirement to protect and recognise the rights of children and wives, marriages between people of different religions that are not legalised nullify the rights of wives and children born from such marriages. Interfaith marriages negate the inheritance rights between husband and wife and their children. In addition to inheritance rights, interfaith families will also 
experience problems in the dispute resolution process in court, whether the religious court is authorised to adjudicate cases between Muslim parties or the state court entitled to adjudicate cases of non-Muslim parties. Dispute resolution is slow and convoluted.

Inherently, Indonesia prohibits interfaith marriage, which can be seen from several religions' various rules and statements. However, this does not condemn the Indonesian people for carrying out interfaith marriages in various ways (Judiasih, Asrimayasha, \& Sudini, 2019). Merely, interfaith marriages carry heavy social responsibilities: the couple must be ready to be ostracised by society (Çiğdem, 2015).

\section{Local Values of Manado: A Buttress for Interfaith Marriages}

North Sulawesi contains various tribes and ethnicities, with Minahasa being the most prominent tribe. Bolaang Mongondow, Sangihe directly adjacent to the Philippines, previously the Gorontalo tribe was included in the North Sulawesi region, which later separated itself into its independent province. In addition to various inland ethnicities, various outland ethnic groups present in North Sulawesi include Arab, Chinese, Javanese, Sumatran, and Kalimantan. Subcultures also existed on this island, like the clans' group of Mamentu, Mamonto, Manopo, Makalunsenge, Paputungan, Karim, etc. The same is true for religious sub-cultures. For example, religious subcultures are consisting of Islam and Catholicism. Protestants, Hindus, Buddhists, Confucians, and religious sects on the island of Sangihe are known as the Masaade community or old Islam. Within such religion, various sects exist like Sunni and Shiite in Islam, etc.

Building trust across individuals and groups by increasing the intensity of encounters or meetings (Bakudapa) is the local wisdom of society in Sulawesi, especially Manado. The people of Manado grow and tighten their social relationships through the habits of basingga (stopping by) and bakudapa-bacarita (meeting-telling) as an integral part of the daily interactions of the Manado people. Bakudapa-bacarita is a sign of tightening the friendship and brotherhood.

Bakudapa can also mean dialogue in a general sense. In this case, bakudapa is the main prerequisite for building a dialogical and dynamic relationship. At the same time, bakudapa can be an excellent medium to manage disputes and prevent or minimise the possibility of other conflicts due to different perspectives. In short, the bakudapa is an early rarity for the bakubae (peace). Meanwhile, bakubae are an ideal solution for reconciliation and rehabilitation. In this perspective, the bakudapa process carried out by Muslims and Christians in the tradition of the feast of the valve is one of the fundamental aspects for a culturally based dialogue process in depth for conflict resolution.

The bakudapa habit is a daily activity for the people of Manado. In bakudapa there is a process of listening to each other, respecting each other's position, and understanding each other. Suppose some conditions require forgiveness, then through bakudapa and the internalisation process among others. In that case, forgiveness is given so that there is a genuine acceptance of one another. this condition is the foundation of the bakubae.

In a multicultural society, contact between people of different identities or bakudapa is a sociological consequence. This contact even manifested in marriage bonds, between Minahasa people with Bolaang Mongondow, Sangihe with Gorontalo people, Arabs with Javanese, even inter-religious marriages, especially between Muslims and Christians Bakukaweng.

The people of North Sulawesi are get used to differences, taking care of each other, and respecting one another as a daily scene of inter-religious interactions. When many Muslims in other regions in Indonesia call out against giving greetings or wishing a merry Christmas to the Christians, Muslims in North Sulawesi spread the banners in many corners of the city saying merry Christmas from the Muslim community. Everyone does not hesitate to mention that one has relatives or parents of different religions and, in fact, tightens their relationship with other religions in North Sulawesi.

Bhineka Tunggal Ika means unity in diversity, is represented Indonesia as a nation with multi-ethnic groups, languages, cultures, and religions. Indonesian society is a pluralistic society, especially in terms of ethnicity and religion. Indonesian people in living their lives are faced with fundamental differences 
in various ways. Thus, interreligious marriage could not be avoided, and the government should respond to this practice and give a solution through its regulation.

The pattern of interfaith communication in Manado does not emphasise the religious aspect, because religion falls within the individual responsibility towards God. In Manado, the principle of torang samua basudara, torang samua ciptaan Tuhan (we are bound through kinship, and we are all God's creation) is the basis for relationships. Thus, the emphasis on relationships that are promoted in Manado is based on the kinship system (Stanley, Personal Communication, July 26, 2018). Deny Pinontoan also mentions that interfaith marriages still occur until now and sociologically it is unproblematic. Since the beginning where the native and the immigrant are in contact in North Sulawesi, interfaith marriages had already occurred (Deny Pinontoan, Personal Communication, July $29,2018)$.

\section{The Practice of Interfaith Marriage: Managing Love, Respect, and Tolerance}

In Indonesia, marriages between Muslims and non-Muslims used to be easy and quite common, especially in Central Java and Yogyakarta. Local registrars often find ways to accommodate dual religious couples seeking to marry (Jones, Leng, \& Mohamad, 2009). The data obtained by Aini in Jakarta shows 3,447 interfaith married couples (or an average of 138 cases per year) registered their marriage at the Civil Registry Office between 1975 to 1999. In 1980, at least 1.5\% of married couples in Yogyakarta were interreligious. That figure increased to 1.8\% in 1990 (Aini, 2008). Among nonMuslims, this figure is much higher, around 5\% in 1980, 1990, and 2000 (Aini et al., 2019).

Apart from Java, North Sulawesi, especially Manado, also had several cases of inter-religious marriages. This article provides the story of interreligious marriages experienced by participants of this study-for example, the marriage of Toar Palilingan, who is Christian with his Muslim wife. The marriage, which took place in 1982 last longer and harmoniously up to 2010, when his wife passed away. At the beginning of their marriage, they did not get approval from the family of Toar's wife, who is Muslim (Toar Palilingan, Personal Communication, July 25, 2018). However, as time goes by, the family can accept it, so they decide to marry according to their respective religions. The first marriage is based on Christianity and then carried out based on Islam without baptising the bride and groom.

After marriage, they are compiling their marriage to be recorded to the District Court and registered at the Civil Registration Service office. During their marriage, opposition came from friends and relatives of both sides. Many of them suggested to each spouse, Toar and his wife, that both invite each to join one religion. However, Toar and his wife believe that all faiths they profess are true and no need to force someone, especially the loved one, to convert. Toar and his wife remain adamant in maintaining the harmony of their marriage with tolerance and defending each other's religions.

From this marriage, Toar Palilingan and his wife have a son. Both of them do not force their son to follow one of their religion, but instead, leave it to their son's choice. The son rather chooses Jew as his religion. Toar did not question his son's choice of religion as long as he is a good adherent of the religion. Toar builds religious harmony within his family based on mutual tolerance, understanding, and awareness and does not force the family member to follow one religion. He said:

My family upholds religious freedom. I give my wife and children the freedom to worship. On every religious celebration day, such as Eid al-Fitr, their families visit each other. During the month of Ramadan, I respect my wife who is doing fasting. I believe that everyone's freedom to practice their religion and freedom of religion will give birth to a tolerant attitude in religious life. This kind of attitude will never be present in the people who do not respect their beliefs (Toar Palilingan, Personal Communication, July 25, 2018).

The principle of interfaith marriage carried out by Toar is prioritising the meeting point of religious goals and religious teachings. He believes that all religions have the same principles, namely educating people to behave appropriately and correctly based on the substance and essence teachings in their respective religions. All religions teach universal truth values, such as compassion, peace, respect, mutual help, justice, etc. 
Endang Kadir experiences another example of a successful interreligious marriage. Endang, a Muslim, married her husband, who is Christian. They met for a short period but immediately decided to get married. Endang's family did not oppose her marriage.

We have been married to this day for 17 years. At first, my husband's family opposed our marriage, but in the end, they agreed. Before we married, we do not have a long courtship, but we directly got married. Now, my husband converted to Islam (Endang Kadir, Personal Communication, July 22, 2018).

Endang and her husband can manage their marriage well. There were no problems related to their belief. They still have no child yet. Endang said that the most important aspect in maintaining a family with different religions is respecting and appreciating one another.

There should be no coercion, we manage maturely in responding to our differences. When we manage to be tolerant in the family, we can do it in the society in general (Endang Kadir, Personal Communication, July 22, 2018).

The principle of marriage used by Endang in undergoing interfaith marriages is to promote an open-minded attitude and tolerance. The existence of religious plurality is the destiny and will of God Almighty. Islamic teachings teach us to be generous and to be tolerant of the diversity of religions. Endang's tolerant and open attitude made her marriage last. Even her husband, who was previously non-Muslim, later chose to take the shahada and embrace Islam.

Other cases of interfaith marriages are experienced in Valentin's marriage. Valentin converted to Islam amid the challenges of her family. After marriage, she returned to Christian because she felt unguided. However, she manages the marriage well. Her husband supported her with her religious activities. Whenever she needs to attend church, he will drop her there. They also help each other preparing religious celebrations for each partner (Valentin, Personal Communication, April 20, 2018). This harmonious interreligious marriage also happens in Ida's family (a pseudonym). Ida is married to her husband, who is Christian and active in his church activities. Meanwhile, she is also active in mosque activities. They help each other organise religious festivals and do community service (Ida, Personal Communication, June 27, 2018).

These interreligious marriages presented in this study have the same principle in managing their harmonious marriage, namely tolerance and mutual respect for the beliefs held by their respective partners. By implementing the principle of tolerance, interfaith marriages can be maintained well.

Interfaith marriages that practiced in North Sulawesi did not always run smoothly. This study also found that several cases failed. The main factor was unpreparedness in dealing with differences between partners, even though the trigger was not solely related to different religions. Still, other factors made interfaith marriages untenable, for example, economic factors, different cultures, and the emergence of awareness on the legal status of marriage that is not recognised by the state.

This was experienced by one of the informants, Mimin Parera. Mimin married at quite young when she was about 19 years old. She is a devout Muslim and from religiously fanatical family background. She married a Protestant. To received approval from Mimin's parents, her prospective husband 'pretended' to be a Muslim. However, during the marriage, they experienced conflict especially related to the legal status of their marriage (Mimin Parera, Personal Communication, March 6, 2018). Several fail interreligious marriages are caused by converting one spouse following the other religion. However, when the marriage did not work out, one will return to the religion of origin as experienced by Rivai Madabi (Rivai Madabi, Personal Communication, March 20, 2018).

Maryam Patutungan also experienced the failure of an interreligious marriage. When she and her husband decided to get married, they agreed to keep their religion. However, later in their marriage, he forced her to convert to her husband's religion, Christian, because of her husband's ego. Maryam refused it and asked for divorce instead (Maryam Paputungan, Personal Communication, February 14, 2018).

From the examples of interfaith marriages above, it can be seen that some successful marriages enforce a communication pattern of democracy and tolerance in the family. This can be proven by the 
existence of communication between husband and wife in determining the religion of their children, providing the widest opportunity for their partners to practice religious teachings based on beliefs, even taking them to places of worship and helping prepare for each of religious celebration.

Due to the difficulty in gaining the legal status of interreligious marriage, several couples converted to one of the spouse religions either for real or pretended. The pattern of interreligious marriage as experienced by the informants above and also by several other respondents are 1) each partner maintains their original religion (baku tahang agama) (Abdurrahman Konoras, Personal communication, June 10, 2018), 2) lives with one religion (Nasruddin Yusuf, Personal Communication, May 25, 2018), 3) wives follow their husbands for reasons of children stability, 4) When each of the spouses could not respect one religion divorce took place (Subardi Moodut, Personal Communication, October 27, 2018).

Several aspects should be considered in interreligious marriage: first, maintain the relationship of tolerance, respect for each other, help each other, or even remind each other about the teachings of each other's religions. Second, never force one religion into the family members, neither the partner nor the children. Third, strengthen each other beliefs and support each other in practising religion.

The pluralistic condition of North Sulawesi makes the community prepared in facing differences. The awareness of diversity in the community also helps them maintain social activities. Several problems may also occur, especially related to politics, economics and hot issues arrived from the national level like the case of Ahok. However, the people in North Sulawesi can maintain and reduce the conflict because of their bond based on the kinship system. This kinship system tightens the bond of people in North Sulawesi. Apart from interreligious marriage practice in North Sulawesi, they also practice interethnic marriage.

Thus, this article argues that in terms of communal level, this interreligious marriage is legal. However, the consequences of this practice, they may lose their constitutional rights as stated by the requirement of a valid marriage.

\section{5. 'Torang Samua Basudara': The Principle in an interfaith marriage in Manado}

The term torang samua basudara is the motto of the people of North Sulawesi who live to maintain the harmony and peace of the people in this region (Rajafi, 2016). The harmonious family life that consists of different religions for its member can be maintained. The basic principle is love and compassion among the family members (Parker, Hoon, \& Raihani, 2018). Kalesaran and his son experienced this kind of life where he is as the father is Christian while his son is Muslim. They live happily without any significant problem related to the different religions (Kalesaran, Personal Communication, June 20, 2018).

Çiğdem (2015) also reported that:

To the rest, I say, not the Lord, that if any brother has a wife who is an unbeliever, and she consents to live with him, he should not divorce her. If any woman has a husband who is an unbeliever, and he consents to live with her, she should not divorce her. Because an unbelieving husband is purified through his wife, and an unbelieving wife is purified through her husband.

This opinion aligns with the principle of life in North Sulawesi torang samua basudara which means they are all brothers/sisters and no one should hurt each other. The conflict can be prevented as everyone respects each other, including in religious beliefs.

Concerning the legal uncertainty of interfaith marriage in Indonesia, research by Suhasti, Djazimah, and Mada (2018) shows that interfaith marriages based on the provisions of the State court are considered valid as long as the marriage follows the rituals/rules of one of the spouses' religious beliefs. Regarding marriage registration for legal events or actions experienced by the community, as stated by the Department of Civil Registry Affairs, there has been no synchronisation with the marriage law that has implications for non-contradiction in forming the legal structure. When a marriage is based on the provisions of the District Court but does not follow the rituals or rules of a particular religious 
belief, it implies not only a tendency to 'smuggle' the law by the people but also to the refutes among the judges when having decisions related to judicial reasons.

In addressing the legal uncertainty regarding interfaith marriage, one example that can be taken is the case of Vony and Andrianus where the Supreme Court permitted them to practice interfaith marriage. The Supreme Court's resolution in accepting interfaith marriages based on the general principles enshrined in the constitution is sufficient evidence to the regulation and laws on interfaith marriage, including Islamic law, to reconsider its decision that accommodates interfaith marriage in Indonesia (Lukito, 2008).

\section{Conclusion}

Marriage is an important life stage in the Indonesian community. The diversity of Indonesian cultures, ethnicities, and religions enable each person to interact with one another. In the process of socialising, meeting people from different cultural and religious backgrounds is unavoidable, including attracting and developing love feelings. In Manado for example, as this article shows, interfaith marriage is a common phenomenon, and the community accepts this practice. North Sulawesi as a region with diversity in terms of ethnicity and religion, bound its community through the principle of torang semua basudara. This principle bound the community of respecting people based on kinship system, not religion. Thus, several interfaith marriages successfully maintain harmony for the respect and tolerance of each other's beliefs. Interfaith marriage will always occur in Indonesia as part of a multi-religious belief. In this regard, Indonesian marriage law should accommodate this interfaith marriage. However, today's law on interfaith marriage is still uncertain, making several people lose their constitutional rights. In this regard, Indonesian marriage law should be reviewed to accommodate this interfaith marriage.

\section{References}

Abubakar, A. (2008). Perkawinan Muslim dengan Non-Muslim Dalam Peraturan Perundang-undangan, Jurispundensi dan Masyarakat (Ali \& Saifan, eds.). Nangroe Aceh Darussalam: Dinas Syariat Islam Provinsi NAD.

Aini, N. (2008). Inter-religious Marriage from Socio-Historical Islamic Perspectives. BYU Law Review, 669.

Aini, N., Utomo, A., \& McDonald, P. (2019). Interreligious Marriage in Indonesia. Journal of Religion and Demography, 6(1), 189-214. https://doi.org/10.1163/2589742x-00601005

Baso, A., \& Nurcholis, A. (2010). Perkawinan Beda Agama; Kesaksian, Argumen Keagamaan, dan Analisis Kebijakan. Jakarta: IPRC-Komnas HAM.

Çiğdem, R. (2015). Imterfaith Marriage in Comparative Perspective. Acta Orientalia Academiae Scientiarium Hung, 68(1), 59-86.

Hutapea, B. (2011). Dinamika Penyesuaian Suami-Istri Dalam Perkawinan Beda Agama. Jurnal Pusat Penelitian Dan Pengembangan Kesejahteraan, 16(1), 101-122. https://doi.org/10.33007/ska.v16i1.795

Imam, I. (2016). Shariah and Human Rights Perspectives on Interfaith Marriage : Challenges Impeding Its Practice in Nigeria. Islam and Civilisational Renewal (ICR), 7(4), 492-508. https://doi.org/10.12816/0035217

Islam, Z. (2014). Interfaith Marriage in Islam and Present Situation. Global Journal of Politics and Law Research, 2(1), $36-47$.

Jauhari, M. S., \& Ghoni, A. (2020). The Level of People's Obedience to MUI Fatwas (COVID-19, Bank Interest, and Interfaith Marriage). AHKAM : Jurnal Ilmu Syariah, 20(2), 233-256. https://doi.org/10.15408/ajis.v20i2.18685

Jihaduddin, M. (2015). Konversi agama sebab perkawinan dan implikasinya terhadap keharmonisan rumah tangga: Perpektif elit agama Islam dan Kristen di Kota Malang. Universitas Islam Negeri Maulana malik Ibrahim.

Jones, G. W., Leng, C. H., \& Mohamad, M. (Eds.). (2009). Muslim-non-Muslim marriage: Political and cultural contestations in Southeast Asia. Institute of Southeast Asian Studies. https://doi.org/10.1355/9789812308221

Judiasih, S. D., Asrimayasha, N., \& Sudini, L. P. (2019). Prohibition of Intera Religion Marriage in Indonesia. Jurnal Dinamika Hukum, 19(1), 186-203. https://doi.org/10.20884/1.jdh.2019.19.1.2462

Kurttekin, F. (2020). Religious Education of Children in Interfaith Marriages. Journal of Beliefs \& Values, 41(3), 272283.

Lukito, R. (2008). The Enigma of Legal Pluralism in Indonesian Islam: the Case of Interfaith Marriage. Journal of Islamic Law and Culture, 10(2), 179-191.

Mantu, R. (2018). Memaknai “Torang Samua Basudara”(Manajemen Dakwah Berbasis Kearifan Lokal di Kota 
Manado). Potret Pemikiran, 19(2), 42-65. https://doi.org/10.30984/pp.v19i2.731

Muhammad, N. E. (2020). Realitas Perkawinan Beda Agama Perspektif Keluarga Sakinah. Al-Mizan, 16(2), $273-$ 298. https://doi.org/10.30603/am.v16i2.1830

Parker, L., Hoon, C.-Y., \& Raihani. (2018). Young People's Attitudes towards Inter-Ethnic and Inter-Religious Socializing , Courtship and Marriage in Indonesia Young People's attitudes towards inter- ethnic and interreligious socializing, courtship and marriage in Indonesia. South East Asia Research, 22(4), 467-486. https://doi.org/10.5367/sear.2014.0230

Patricktts. (2010). Kebijakan Kriminal Tentang Perbuatan Pegawai Catatan Sipil Dalam Pencatatan Perkawinan Beda Agama [Criminal Conduct Policy for Civil Registry's Employees in Registering Interreligious Marriage]. Sekolah Tinggi Hukum Bandung.

Rajafi, A. (2016). Resolusi Konflik Keluarga Berbasis Local Wisdom (Reaktualisasi Filosofi Masyarakat Sulawesi Utara Torang Samua Basudara). Yudisia, 7(1), 1-16.

Ruandini, G. (2011). Komunikasi Antarpersonal dalam Kerukunan Umat Beragama Studi Fenomenologi pada Masyarakat Desa Balun Kecamatan Turi Kabupaten Lamongan. University of Muhammadiyah Malang.

Sant-Cassia, P. (2018). Marriages at The Margins: Interfaith Marriages in The Marriages at The Mediterranean. Journal of Mediterranean Studies, 27(2), 111-132.

Sintang, S., Khambali, K. M., Baharuddin, A., \& Ahmad, M. (2014). Interfaith Marriage and Religious Convertion: a Case Study of Muslim Converts in" Sabah", Malaysia. The Ahfad Journal, 31(1), 46.

Suhasti, E., Djazimah, S., \& Mada, G. (2018). Polemics on Interfaith Marriage in Indonesia Between Rules and Practices. Al-Jami'ah: Journal of Islamic Studies, 56(2), 367-394. https://doi.org/10.14421/ajis.2018.562.367-394

Syatriadin, S. (2019). Kerukunan Umat Beragama dalam Konteks Keluarga Beda Agama. AL-FURQAN, 8(1), 3749.

Van Niekerk, J., \& Verkuyten, M. (2018). Interfaith marriage attitudes in Muslim majority countries: A multilevel approach. The International Journal For The Psychology Of Religion, 28(4), 257-270.

Yusuf, M. (2013). Pendekatan al-Mașlaḥaḥ al-Mursalah dalam Fatwa MUI tentang Pernikahan Beda Agama. AHKAM : Jurnal Ilmu Syariah, 13(1), 99-108. https://doi.org/10.15408/ajis.v13i1.955

Zuriyati, Yaswirman, \& Yasniwati. (2019). Registration of Interfaith Marriages at the Civil Registry Office in Pekanbaru. International Journal of Multicultural and Multireligious Understanding, 6(5), 895-900. https://doi.org/http://dx.doi.org/10.18415/ijmmu.v6i5.1181

(C) 2021 by the authors. Submitted for possible open access publication under the terms and conditions of the Creative Commons Attribution (CC BY SA) license (https://creativecommons.org/licenses/by-sa/3.0/). 